\title{
PENGARUH KECEPATAN PUTAR TERHADAP UNJUK KERJA MESIN PENCACAH PELEPAH KELAPA SAWIT (CHOPPER)TIPE TEP-1
}

\section{THE EFFECT OF SPEED ROTATION TO THE PERFORMANCE OF PALM OIL MIDRIB CHOPPER MACHINE TEP-1 TYPE}

\author{
Muchsin Andrian Soni Rala $^{1}$, Sandi Asmara ${ }^{2}$, Siti Suharyatun ${ }^{3}$ \\ ${ }^{1}$ Mahasiswa Teknik Pertanian, Fakultas Pertanian, Universitas Lampung \\ 2,3 Dosen JurusanTeknik Pertanian, Fakultas Pertanian, Universitas Lampung \\ ${ }^{\square}$ Komunikasi penulis, email: mandiansonirala86@gmail.com \\ Naskah ini diterima pada 2 November 2017; revisi pada 21 November 2017; \\ disetujui untuk dipublikasikan pada 28 Desember 2017
}

\begin{abstract}
The palm oil frond contains $6.50 \%$ crude protein, $32.55 \%$ crude fiber, $4.47 \%$ crude fat, $93.4 \%$ dry matter and $56.00 \%$ TDN. The result of analysis shows that the crude protein content of palm leaf midrib is quite low at $6.5 \%$ with a high crude fiber of $32.55 \%$, which can potentially be used as animal feed The main obstacle in the utilization of oil palm buckling is its hard physical properties so it can not be directly utilized for animal feed. Processing technology required palm oil to be used for animal feed, one of them with chopping technology (chopping). The aim of this research is to know the best rotation speed on TEP-1 type chopper machine to work capacity, losses, chopped diversity, and fuel consumption. This research was conducted in July - August 2017 in Batuliman Indah village, Candipuro district, South Lampung regency. The tool used in this research is TEP-1 type chopper machine, stopwatch, tachometer, scales, sack, ruler, and stationery. The material used is palm oil stem waste with a uniform length of 5 meters and diesel fuel. The result of research, rotation speed is influence all parameters. The best rotation speed to work capacity, losses, and chopped diversity is 1200 RPM to 1600 RPM, while the best rotation fuel consumption is $1200 \mathrm{RPM}$, due to less consumption but performance results same as 1600 RPM. The percentage of chopping that can be used directly as livestock is 37\% - 44\%. This study recommends the use of rotational speed between 1200 RPM to 1600 RPM.
\end{abstract}

\section{Keywords: Oil palm mibrid, Chopper Type TEP 1, Speed rotation.}

\begin{abstract}
ABSTRAK
Indonesia merupakan negara yang dikenal sebagai produsen minyak sawit dunia. Salah satu produk samping tanaman perkebunan sawit yang belum dimanfaatkan secara optimal adalah limbah pelepah kelapa sawit Kendala utama dalam pemanfaatan pelepah kelapa sawit adalah sifat fisiknya yang keras sehingga tidak bisa langsung dimanfaatkan untuk pakan ternak, Sehingga diperlukan teknologi pengolahan pelepah kelapa sawit agar bisa dimanfaatkan untuk pakan ternak, salah satunya dengan teknologi cacahan (chopping). Jurusan Teknik Pertanian Universitas Lampung telah memodifikasi dan membuat alat Mesin pencacah (Chopper) Tipe TEP-1 yang digunakan untuk mencacah pelepah kelapa sawit sebagai bahan baku pakan ternak. Tujuan penelitian ini adalah mengetahui pengaruh kecepatan putar mesin pencacah (chopper) tipe TEP-1 terhadap kapasitas kerja, susut bobot, dan keberagaman cacahan pelepah kelapa sawit. Penelitian ini dilaksanakan pada bulan Juli - Agustus 2017, di Desa Batuliman Indah, Kecamatan Candipuro, Kabupaten Lampung Selatan, Provinsi Lampung. Penelitian ini dilakukan dalam 6 tahap (1) persiapan alat dan bahan. (2) pencacahan pelepah kelapa sawit (3) pengukuran hasil cacahan. (4) penghalusan yang dilakukan 1 kali pada setiap perlakuan (5) penimbangan. (6) analisis data. Parameter yang diamati pada penelitian ini adalah waktu kerja pencacahan $(\mathrm{t})$, kapasitas kerja (ka), susut bobot (sb), dan keberagaman cacahan (kc). Penelitian ini, pelepah kelapa sawit diambil dari kebun kelapa sawit milik warga. Berdasarkan penelitian dan pengamatan, diambil kesimpulan Kecepatan putar (RPM) berpengaruh terhadap kapasitas kerja, susut bobot, keberagaman cacahan, dan konsumsi bahan bakar, Kecepatan putar pencacah terbaik berkisaran antara $1200-1600 \mathrm{Rpm}$.
\end{abstract}

Kata Kunci : Pelepah kelapa sawit, mesin pencacah Tipe TEP-1, Kecepatan putaran. 


\section{PENDAHULUAN}

Indonesia merupakan negara yang dikenal sebagai produsen minyak sawit dunia. Kondisi geografis Indonesia yang subur dengan panas matahari yang cukup dan curah hujan cukuptinggi sangat cocok untuk tanaman kelapa sawit. Hal ini membuat perkembangan lahan perkebunan sawit di Indonesia selalu mengalami peningkatan setiap tahunnya (Hermawan,2015). Salah satu produk samping tanaman perkebunan sawit yang belum dimanfaatkan secara optimal adalah limbah perkebunan kelapa sawit. Pelepah merupakan salah satu limbah yang dihasilkan dari tanaman sawit. Limbah ini mengandung bahan kering, protein kasar dan serat kasar yang nilai nutrisinya dapat dimanfaatkan sebagai bahan dasar pakan ternak ruminansia. Hasil penelitian yang dilakukan Sianipar (2009), pelepah daun kelapa sawit mengandung 6,50\% protein kasar, 32,55\% serat kasar, 4,47\% lemak kasar, 93,4\% bahan kering dan 56,00\% TDN. Hasil analisis memperlihatkan bahwa kandungan protein kasar pelepah daun kelapa sawit cukup rendah yaitu sebesar 6,5\% dengan serat kasar yang cukup tinggi sebesar 32,55\%, sehingga berpotensi dapat dimanfaatkan juga sebagai pakan ternak.

Kendala utama dalam pemanfaatan pelepah kelapa sawit adalah sifat fisiknya yang keras sehingga tidak bisa langsung dimanfaatkan untuk pakan ternak. Sehingga diperlukan teknologi pengolahan pelepah kelapa sawit agar bisa dimanfaatkan untuk pakan ternak, salah satunya dengan teknologi cacahan (chopping). Chopping atau mencacah adalah teknik merubah tekstur dan ukuran partikel bahan agar konsumsi ternak menjadi lebih efisien. Alat yang dapat digunakan untukpengolahan tersebut adalah chopper atau mesin pencacah. Alat ini berfungsi merubah bentuk lonjoran pelepah sawit menjadi cacahan atau potongan kecil. Dengan bentuk cacahan tersebut limbah pelepah sawit akan lebih mudah untuk dimanfaatkan menjadi bahan pakan ternak (Yusuf dkk,2014).

Mesin pencacah (Chopper) telah banyak beredar dipasaran namun masih banyak kekurangan terutama pada ukuran hasil cacahan yang masih terbilang kasar. Jurusan Teknik Pertanian Universitas Lampung telah memodifikasi dan membuat alat Mesin pencacah (Chopper) Tipe TEP-1 yang digunakan untuk mencacah pelepah kelapa sawit sebagai bahan baku pakan ternak. Mesin pencacah (Chopper) Tipe TEP-1 dilengkapi mekanisme pencacah yang efisien dengan menggunakan dua pisau, yaitu pisau pencacah dan pisau penghalus.Sistem kerja mesin pencacah (Chopper) Tipe TEP-1 adalah pisau pencacah memotong bahan dengan berputar vertikal kearah gerak bahan lalu masuk pada pisau penghalus yang bertujuan memperkecil hasil cacahan.

Namun perlu pengujian lanjutan untuk mengetahui kapasitas kerja dan efisiensi dari mesin pencacah pelepah sawit untuk bahan baku pakan ternak. Salah satu parameter yang berkaitan dengan unjuk kerja Mesin pencacah (Chopper) Tipe TEP-1 adalah kecepatan putar RPM (RotationPer Minute), yang berpengaruh terhadap tingkat kehalusan hasil cacahan. Tujuan penelitian ini adalah mengetahui kecepatan putar terbaik mesin pencacah (chopper) tipe TEP-1 terhadap kapasitas kerja, susut bobot, dan keberagaman cacahan pelepah kelapa sawit.

\section{BAHAN DAN METODE}

\subsection{Waktu dan Tempat Penelitian}

Penelitian ini dilaksanakan pada bulan Juli Agustus2017, di Desa Batuliman Indah, Kecamatan Candipuro, Kabupaten Lampung Selatan, Provinsi Lampung.

\subsection{Alat dan Bahan}

Bahan yang digunakan dalam penelitian ini adalah pelepah kelapa sawit dan bahan bakar solar. Alat yang digunakan dalam penelitian ini adalahstopwatch, tachometer, ember, tabung ukur, dan mesin pencacah pelepah kelapa sawit (Chopper) Tipe TEP-1.

\subsection{Mesin Pencacah Tipe TEP-1}

Mesin pencacah yang digunakan adalah mesin pencacah pelepah kelapa sawit (Chopper) Tipe TEP-1 yang dibuat oleh dosen Jurusan Teknik Pertanian, Universitas Lampung. Mesin pencacah pelepah kelapa sawit ini memiliki beberapa bagian, yaitu hopper, tabung pencacah, pisau, pulley, tangki bahan bakar, motor penggerak, dan exhaust. Mesin pencacah ini juga memiliki spesifikasi yang dapat dilihat pada Tabel 1. 
Tabel 1. Spesifikasi Chopper Tipe TEP-1

\begin{tabular}{|c|c|c|c|}
\hline Komponen & Bagian-Bagian & \multicolumn{2}{|c|}{ Keterangan } \\
\hline \multirow{3}{*}{ Penggerak } & \multirow{3}{*}{ Motor Diesel } & Merk & Yamaoke \\
\hline & & Daya & $16,5 \mathrm{PK}$ \\
\hline & & Jumlah Silinder & 1 \\
\hline \multirow{21}{*}{ Alat Pencacah } & \multirow{3}{*}{ Dimensi Pencacah } & Lebar & $80 \mathrm{~cm}$ \\
\hline & & Panjang & $150 \mathrm{~cm}$ \\
\hline & & Tinggi & $100 \mathrm{~cm}$ \\
\hline & \multirow{2}{*}{ Material } & Rangka & Besi Siku \\
\hline & & Body & Besi Plat \\
\hline & \multirow{2}{*}{ Hopper } & Lebar & $9 \mathrm{~cm}$ \\
\hline & & Panjang & $12 \mathrm{~cm}$ \\
\hline & \multirow{5}{*}{ Pisau Pemotong } & Bahan & Besi Baja \\
\hline & & Lebar & $4 \mathrm{~cm}$ \\
\hline & & Panjang & $12 \mathrm{~cm}$ \\
\hline & & Jumlah & 12 \\
\hline & & Tebal & $1,5 \mathrm{~cm}$ \\
\hline & \multirow{6}{*}{ Pisau Pencacah } & Bahan & Besi Baja \\
\hline & & Lebar & $2,5 \mathrm{~cm}$ \\
\hline & & Panjang & $30 \mathrm{~cm}$ \\
\hline & & Diameter & $20 \mathrm{~cm}$ \\
\hline & & Jumlah & 3 \\
\hline & & Tebal & $0,8 \mathrm{~cm}$ \\
\hline & \multirow{3}{*}{ Saluran Output } & Bahan & Besi Plat \\
\hline & & Lebar & $30 \mathrm{~cm}$ \\
\hline & & Panjang & $40 \mathrm{~cm}$ \\
\hline \multirow{3}{*}{ Transmisi } & \multirow{2}{*}{ Pulley } & Pada Poros Pisau & 7 in \\
\hline & & Pada Motor & 5 in \\
\hline & $V$-Belt & & B-46 \\
\hline
\end{tabular}

\subsection{Metode Penelitian}

Penelitian ini dilakukan melalui beberapa tahap:

1. Persiapan mesin pencacah pelepah kelapa sawit (chopper) Tipe TEP-1

2. Pengumpulan pelepah kelapa sawit.Pelepah kelapa sawit yang digunakan dibuat seragam dengan panjang 5 meter.

3. Mencacah pelepah kelapa sawit dengan tiga variasi kecepatan putar
a. $800 \mathrm{RPM}$
b. $1200 \mathrm{RPM}$
c. $1600 \mathrm{RPM}$

4. Pengukuran Hasil cacahan

5. Penghalusan
6. Penimbangan hasil cacahan

\section{Analisis Data}

\subsection{Parameter Pengamatan}

\subsubsection{Waktu Kerja Pencacahan (t)}

Parameter yang digunakan adalah dicari untuk menentukan RPM mana yang paling baik agar memperoleh efektivitas kerja yang optimal. Waktu kerja pencacahan dihitung dari lama waktu yang dibutuhkan dalam sekali proses, yaitu untuk memotong pelepah sebanyak 10 buah. Waktu pencacahan diukur menggunakan stopwatch. 


\subsubsection{Kapasitas Kerja (ka)}

Kapasitas kerja alat dihitung dari perbandingan berat hasil cacahan pelepah kelapa sawit yang keluar dari mesin pencacah (chopper) tipe TEP1 tiap satu jam. Perhitungan kapasistas kerja menggunakan persamaan 1 .

$k a=\frac{B O}{t} \times 3600$

$\mathrm{ka}=$ kapasitas kerja

BO = Bahan Output (massa pelepah kelapa sawit yang telah dicacah)

$\mathrm{t}$ = waktu (detik)

\subsubsection{Susut bobot (sb)}

Susut bobot dihitung berdasarkan perbandingan berat akhir (berat hasil cacahan pelepah yang dihasilkan) dengan berat awal (berat pelepah yang digunakan) dikalikan 100\% (Sani dkk, 2014). Susut bobot dihitung menggunakan persamaan (2)

Susut bobot $=\frac{(B I-B O)}{B I} \times 100 \%$.

$\mathrm{BI}=$ Bahan input

$\mathrm{BO}=$ Bahan output

\subsubsection{Keberagaman Cacahan (kc)}

Ukuran output cacahan yang digunakan sebagai kriteria keberhasilan penelitian ini adalah output cacahan pada ukuran $<1 \mathrm{~cm}$ dan $1 \mathrm{~cm}<\mathrm{x}<2,5 \mathrm{~cm}$.

\subsubsection{Konsumsi Bahan Bakar}

Dihitung dengan cara membagi volume bahan bakar yang terpakai dengan berat bahan yang tercacah. Pengukuran awal dihitung setelah motor dipanaskan dengan tujuan agar mesin panas sehingga bahan bakar yang terpakai akan stabil. Pengukuran akhir dihitung setelah hasil cacahan keluar dan mesin pencacah dimatikan. Perhitungan konsumsi bahan bakar pada penelitian ini dilakukan sebanyak tiga kali ulangan dengna menggunakan rumus pada persamaan (3).

$\mathrm{FC}=\frac{F_{2}}{m}$.

$\mathrm{Fc}=$ konsumsi bahan bakar (liter/ton)

$\mathrm{Fv}=$ volume bahan bakar terpakai (liter)

$\mathrm{m}=$ berat bahan hasil cacahan (ton). (Fadli, 2015).

\section{HASIL DAN PEMBAHASAN}

\subsection{Waktu Kerja Pencacahan}

Waktu kerja pencacahan dicari untuk menentukan RPM mana yang paling baik agar memperoleh efektivitas kerja yang optimal. Waktu kerja pencacahan yang tercatat dapat dilihat pada Tabel 2.

Berdasarkan Tabel 2, waktu kerja pencacah yang didapatkan berkisar antara 273 - 485 detik. Analisis sidik ragam menunjukkan bahwa $\mathrm{F}$ hitung $>\mathrm{F}$ tabel ${ }^{0.05}$ yang menjelaskan bahwa nilai RPM berpengaruh terhadap waktu kerja pencacahan. Setelah itu, dilakukan uji BNT yang menunjukkan bahwa perlakuan F3 (RPM 800) berbeda nyata dengan perlakuan lain, namun perlakuan F2 (RPM 1200) dan F1 (RPM1600) tidak berbeda nyata. Hal ini menunjukkan bahwa kecepatan putar 1600 RPM dan 1200 RPM membutuhkan waktu pencacahan lebih

Tabel 2. Data Waktu Kerja Pencacahan

\begin{tabular}{|c|c|c|c|c|}
\hline RPM & Ulangan & Input Pelepah & $\begin{array}{l}\text { Waktu Kerja } \\
\text { (detik) }\end{array}$ & $\begin{array}{c}\text { Rata-rata waktu } \\
\text { (detik) }\end{array}$ \\
\hline \multirow{3}{*}{1600} & 1 & 10 & 262 & \multirow{3}{*}{273} \\
\hline & 2 & 10 & 291 & \\
\hline & 3 & 10 & 265 & \\
\hline \multirow{3}{*}{1200} & 1 & 10 & 286 & \multirow{3}{*}{286} \\
\hline & 2 & 10 & 272 & \\
\hline & 3 & 10 & 301 & \\
\hline \multirow{3}{*}{800} & 1 & 10 & 445 & \multirow{3}{*}{485} \\
\hline & 2 & 10 & 455 & \\
\hline & 3 & 10 & 555 & \\
\hline
\end{tabular}


sedikit dibanding kecepatan putar 800 RPM. Adanya perbedaan hasil waktu kerja pencacahan dipengaruhi oleh kecepatan pisau pemotong. Semakin cepat putaran pisau pemotong, maka bahan tercacah habis semakin cepat.

\subsection{Kapasitas Kerja}

Kapasitas kerja dicari untuk menentukan RPM terbaik yang didapat dengan cara menghitung berat hasil cacahan pelepah kelapa sawit yang keluar dari mesin pencacah (chopper) tipe TEP1 menggunakan timbangan. Kapasitas kerja yang dihasilkan dapat dilihat pada Tabel 3.

Dari Tabel 3 terlihat bahwa perbedaan nilai RPM berpengaruh terhadap kapasitas kerja. Hal ini juga diperkuat dari analisis sidik ragam, yaitu F hitung $>\mathrm{F}$ tabel ${ }^{0.05}$ yang menjelaskan bahwa nilai RPM berpengaruh terhadap kapasitas kerja mesin. Setelah itu, dilakukan uji BNT yang menunjukkan bahwa perlakuan F3 (RPM 800) berbeda nyata dengan perlakuan lain, namun perlakuan F2 (RPM 1200) dan F1 (RPM 1600) tidak berbeda nyata. Hal ini menunjukkan bahwa kecepatan putar 1600 RPM dan 1200 RPM menghasilkan kapasitas kerja lebih tinggi dibanding kecepatan putar 800 RPM.

\subsection{Susut Bobot}

Berdasarkan penelitian yang telah dilakukan menunjukkan bahwa kecepatan putar (RPM) berpengaruh terhadap hasil susut bobot. Data susut bobot dapat dilihat pada Tabel 4 .

Tabel 3. Data Kapasitas Kerja

\begin{tabular}{|c|c|c|c|c|c|c|c|}
\hline RPM & Ulangan & $\begin{array}{l}\text { Input } \\
\text { Pelepah } \\
\text { (buah) }\end{array}$ & $\begin{array}{l}\text { Input } \\
\text { (kg) }\end{array}$ & $\begin{array}{l}\text { Output } \\
\text { (kg) }\end{array}$ & $\begin{array}{c}\text { Efisiensi } \\
\text { waktu } \\
\text { (detik) }\end{array}$ & $\begin{array}{c}\text { Kapasitas } \\
(\mathrm{kg} / \mathrm{jam})\end{array}$ & $\begin{array}{l}\text { Rata-rata } \\
\text { kapasitas } \\
(\mathrm{kg} / \mathrm{jam})\end{array}$ \\
\hline \multirow[t]{3}{*}{1600} & 1 & 10 & 46,06 & 45,81 & 262 & 629.45 & \multirow{3}{*}{607.68} \\
\hline & 2 & 10 & 46,12 & 45,86 & 291 & 567.34 & \\
\hline & 3 & 10 & 46,62 & 46,10 & 265 & 626.26 & \\
\hline \multirow[t]{3}{*}{1200} & 1 & 10 & 46,26 & 45,79 & 286 & 576.38 & \multirow{3}{*}{576.91} \\
\hline & 2 & 10 & 46,04 & 45,64 & 272 & 604.06 & \\
\hline & 3 & 10 & 46,51 & 46,01 & 301 & 550.29 & \\
\hline \multirow[t]{3}{*}{800} & 1 & 10 & 45,91 & 45,03 & 445 & 364.29 & \multirow{3}{*}{341.87} \\
\hline & 2 & 10 & 46,60 & 45,89 & 455 & 363.09 & \\
\hline & 3 & 10 & 46,85 & 45,98 & 555 & 298.25 & \\
\hline
\end{tabular}

Tabel 4. Data Susut Bobot

\begin{tabular}{|c|c|c|c|c|c|c|c|}
\hline RPM & Ulangan & $\begin{array}{l}\text { Input } \\
\text { Pelepah }\end{array}$ & $\begin{array}{c}\text { Berat } \\
\text { Input (BI) } \\
\text { / (Kg) }\end{array}$ & $\begin{array}{c}\text { Berat } \\
\text { Output } \\
(\mathrm{BO}) /(\mathrm{Kg})\end{array}$ & $\begin{array}{c}\text { BI-BO } \\
\text { (Kg) }\end{array}$ & $\begin{array}{c}\text { Rata2 } \\
\text { (BI- } \\
\text { BO)/(Kg) }\end{array}$ & $\begin{array}{c}\text { Susut } \\
\text { Bobot } \\
(\%)\end{array}$ \\
\hline 1600 & 1 & 10 & 46060 & 45810 & 250 & \multirow{3}{*}{343} & \multirow{3}{*}{0.74} \\
\hline & 2 & 10 & 46120 & 45860 & 260 & & \\
\hline & 3 & 10 & 46620 & 46100 & 520 & & \\
\hline \multirow[t]{3}{*}{1200} & 1 & 10 & 46260 & 45790 & 470 & \multirow{3}{*}{457} & \multirow{3}{*}{0.99} \\
\hline & 2 & 10 & 46040 & 45640 & 400 & & \\
\hline & 3 & 10 & 46510 & 46010 & 500 & & \\
\hline \multirow[t]{3}{*}{800} & 1 & 10 & 45910 & 45030 & 880 & \multirow{3}{*}{820} & \multirow{3}{*}{1.77} \\
\hline & 2 & 10 & 46600 & 45890 & 710 & & \\
\hline & 3 & 10 & 46850 & 45980 & 870 & & \\
\hline
\end{tabular}


Dari Tabel 4 terlihat bahwa penggunaan nilai RPM yang berbeda berpengaruh terhadap susut bobot. Hal ini juga diperkuat dari analisis sidik ragam pada tabel 11 , yaitu $\mathrm{F}$ hitung $>\mathrm{F}$ tabel $\mathrm{l}^{0.05}$ yang menjelaskan bahwa nilai RPM berpengaruh terhadap susut bobot. Setelah itu, dilakukan uji BNT pada tabel 12 yang menunjukkan bahwa perlakuan F3 (RPM 800) berbeda nyata dengan perlakuan lain, namun perlakuan F2 (RPM 1200) dan F1 (RPM 1600) tidak berbeda nyata. Hal ini menunjukkan bahwa kecepatan putar 1600 RPM dan 1200 RPM menghasilkan susut bobot lebih sedikit dibanding kecepatan putar 800 RPM.

Dari Tabel 4 menunjukan bahwa RPM tinggi dapat mengurangi hasil susut bobot dari bahan cacahan. Hal ini dikarenakan saat pencacahan menggunakan RPM rendah, yaitu RPM 800 dan 1200 , pelepah kelapa sawit banyak yang tidak tercacah dan keluar dari tabung pisau pencacah. Namun, saat menggunakan RPM 1600, pelepah kelapa sawit tercacah dengan baik dan hanya sedikit yang terbuang. Pada RPM 800 didapat nilai susut bobot sebesar 1,77\%, pada RPM 1200 nilai susut bobot sebesar $0,99 \%$, dan pada RPM 1600 nilai susut bobot sebesar $0,74 \%$.

\subsection{Keberagaman Cacahan}

Hasil cacahan mesin pencacah (chopper) tipe tep-1 seperti yang disajikan pada Tabel 5 akan digunakan sebagai ukuran untuk pakan ternak. Keberagaman cacahan didapat dari perhitungan persentase rerata berat cacahan pelepah kelapa sawit berdasarkan ukuran potongan, yaitu $<1 \mathrm{~cm}$, $1 \mathrm{~cm}<x<2,5 \mathrm{~cm}, 2,5 \mathrm{~cm}<x<5 \mathrm{~cm}$, dan $>5 \mathrm{~cm}$ yang dicacah menggunakan 3 variasi RPM, yaitu RPM 800,1200 , dan 1600 dengan masing-masing ulangan sebanyak 3 kali.

Tabel 5. Data Keberagaman Cacahan

\begin{tabular}{|c|c|c|c|c|c|}
\hline \multirow[t]{2}{*}{ RPM } & \multirow[t]{2}{*}{ Ulangan } & $\begin{array}{c}\text { Berat } \\
\text { potongan } \\
<1 \mathrm{~cm} \\
\end{array}$ & $\begin{array}{c}\text { Berat } \\
\text { potongan } \\
1 \mathrm{~cm}<x<2,5 \mathrm{~cm} \\
\end{array}$ & $\begin{array}{c}\text { Berat } \\
\text { potongan } \\
2,5 \mathrm{~cm}<\mathrm{x}<5 \mathrm{~cm} \\
\end{array}$ & $\begin{array}{c}\text { Berat } \\
\text { potongan } \\
>5 \mathrm{~cm} \\
\end{array}$ \\
\hline & & (gram) & (gram) & (gram) & (gram) \\
\hline \multirow{3}{*}{1600} & 1 & 111 & 334 & 346 & 209 \\
\hline & 2 & 136 & 314 & 301 & 249 \\
\hline & 3 & 151 & 289 & 335 & 225 \\
\hline \multicolumn{2}{|c|}{ Rata-rata (gram) } & 132.7 & 312.3 & 327.3 & 227.7 \\
\hline \multicolumn{2}{|c|}{ Rata-rata (kg) } & 0.133 & 0.312 & 0.327 & 0.228 \\
\hline \multicolumn{2}{|c|}{ Persentase } & 13 & 31 & 33 & 23 \\
\hline RPM & Ulangan & $<1 \mathrm{~cm}$ & $1 \mathrm{~cm}<x<2,5 \mathrm{~cm}$ & $2,5 \mathrm{~cm}<\mathrm{x}<5 \mathrm{~cm}$ & $>5 \mathrm{~cm}$ \\
\hline \multirow{3}{*}{1200} & 1 & 95 & 295 & 321 & 289 \\
\hline & 2 & 86 & 274 & 276 & 364 \\
\hline & 3 & 92 & 265 & 305 & 338 \\
\hline \multicolumn{2}{|c|}{ Rata-rata (gram) } & 91.0 & 278.0 & 300.7 & 330.3 \\
\hline \multicolumn{2}{|c|}{ Rata-rata (kg) } & 0.09 & 0.28 & 0.30 & 0.33 \\
\hline \multicolumn{2}{|c|}{ Persentase } & 9 & 28 & 30 & 33 \\
\hline RPM & Ulangan & $<1 \mathrm{~cm}$ & $1 \mathrm{~cm}<x<2,5 \mathrm{~cm}$ & $2,5 \mathrm{~cm}<\mathrm{x}<5 \mathrm{~cm}$ & $>5 \mathrm{~cm}$ \\
\hline \multirow{3}{*}{800} & 1 & 74 & 199 & 252 & 475 \\
\hline & 2 & 68 & 288 & 235 & 409 \\
\hline & 3 & 69 & 262 & 244 & 425 \\
\hline \multicolumn{2}{|c|}{ Rata-rata (gram) } & 70.3 & 249.7 & 243.7 & 436.3 \\
\hline \multicolumn{2}{|c|}{ Rata-rata (kg) } & 0.07 & 0.25 & 0.24 & 0.44 \\
\hline \multicolumn{2}{|c|}{ Persentase } & 7 & 25 & 24 & 44 \\
\hline
\end{tabular}


Berdasarkan data pada Tabel 5, perbedaan kecepatan putar (RPM) berpengaruh terhadap hasil keberagaman cacahan. Hal ini ditunjukkan pada tabel 5, yaitu setiap perlakuan kecepatan putar menghasilkan berat cacahan yang berbedabeda. Namun seperti yang dikatakan Anizar dkk (2017) bahwa cacahan pelepah sawit dengan ukuran sekitar $5 \mathrm{~cm}$ masih terbilang kasar, sehingga tidak dapat langsung diberikan kepada ternak karena akan melukai lambung ternak sapi, sehingga harus dilakukan penghalusan hingga ukurannya kurang dari $5 \mathrm{~cm}$. Selain itu, ukuran cacahan $1 \mathrm{~cm}<\mathrm{x}<2,5 \mathrm{~cm}$ biasa digunakan untuk pakan ternak di desa Batuliman Indah, Kecamatan Candi Puro, Lampung Selatan. Sehingga, ukuran $1 \mathrm{~cm}<\mathrm{x}<2,5 \mathrm{~cm}$ juga yang digunakan sebagai kriteria keberhasilan penelitian ini. Presentase hasil cacahan ukuran $1 \mathrm{~cm}<\mathrm{x}<2,5 \mathrm{~cm}$ pada tiap RPM dapat dilihat pada Gambar 1.

Kecepatan putar berpengaruh terhadap jumlah persentase hasil cacahan pelepah kelapa sawit ukuran $1 \mathrm{~cm}<\mathrm{x}<2,5 \mathrm{~cm}$ seperti terlihat pada Gambar 1. Uji BNT menunjukkan bahwa kecepatan putar pada 1600 dan 1200 RPM tidak berbeda nyata, tetapi kecepatan putar 800 RPM berbeda nyata dengan perlakuan yang lain, sehingga dapat disimpulkan bahwa persentase hasil cacahan yang dapat langsung digunakan sebagai pakan ternak berkisar antara $37 \%$ $44 \%$.

\subsection{Konsumsi Bahan Bakar}

Konsumsi bahan bakar dihitung untuk melihat seberapa banyak penggunaan bahan bakar dalam mencacah pelepah kelapa sawit per jam. Data konsumsi bahan bakar dapat dilihat pada Tabel 7.

Dapat dilihat pada Tabel 7, dibandingkan RPM 1200 dan 800, RPM 1600 memiliki konsumsi bahan bakar terbanyak, hal ini karena kecepatan putar yang tinggi, sehingga membutuhkan tenaga dan bahan bakar yang lebih banyak untuk mencacah pelepah kelapa sawit.

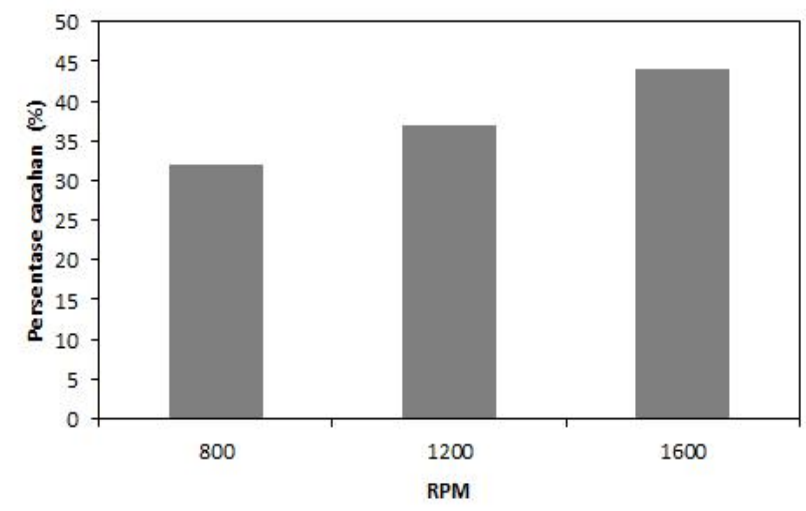

Gambar 1. persentasi hasil cacahan pelepah kelapa sawit

Tabel 7. Data Konsumsi Bahan Bakar

\begin{tabular}{|c|c|c|c|c|c|c|c|c|}
\hline RPM & $\begin{array}{l}\text { BBM } \\
(\mathrm{ml})\end{array}$ & $\begin{array}{l}\text { Waktu } \\
\text { (s) }\end{array}$ & $\begin{array}{l}\text { BBM } \\
(\mathrm{ml} / \mathrm{jam})\end{array}$ & $\begin{array}{l}\text { Rerata } \\
\text { (ml/jam) }\end{array}$ & $\mathrm{kg} / \mathrm{Jam}$ & $\mathrm{l} / \mathrm{kg}$ & l/ton & l/jam \\
\hline & 165 & 262 & 2267.18 & \multirow{3}{*}{2182,98} & 629.45 & \multirow{3}{*}{0.0036} & \multirow{3}{*}{3.588} & \multirow{3}{*}{2.18} \\
\hline 1600 & 177 & 291 & 2189.69 & & 567.34 & & & \\
\hline & 154 & 265 & 2092.08 & & 626.26 & & & \\
\hline & 98 & 286 & 1233.57 & \multirow{3}{*}{1338,58} & 576.38 & \multirow{3}{*}{0.0023} & \multirow{3}{*}{2.313} & \multirow{3}{*}{1.33} \\
\hline 1200 & 109 & 272 & 1442.65 & & 604.06 & & & \\
\hline & 112 & 301 & 1339.53 & & 550.29 & & & \\
\hline & 84 & 445 & 679.55 & \multirow{3}{*}{665,22} & 364.29 & \multirow{3}{*}{0.0019} & \multirow{3}{*}{1.949} & \multirow{3}{*}{0.67} \\
\hline 800 & 86 & 455 & 680.44 & & 363.09 & & & \\
\hline & 98 & 555 & 635.68 & & 298.25 & & & \\
\hline
\end{tabular}


Dari Tabel 7 terlihat bahwa penggunaan nilai RPM yang berbeda berpengaruh terhadap konsumsi bahan bakar. Hal ini juga diperkuat dari analisis sidik ragam, yaitu $\mathrm{F}$ hitung $>\mathrm{F}$ tabel $^{0.05}$ yang menjelaskan bahwa nilai RPM berpengaruh terhadap konsumsi bahan bakar. Setelah itu dilakukan uji BNT yang menunjukkan bahwa perlakuan F3 (RPM 1600) berbeda nyata dengan perlakuan lain, namun perlakuan F2 (RPM 1200) dan F1 (RPM 800) tidak berbeda nyata. Dari analisa yang telah dilakukan, dapat diketahui bahwa RPM 1200 adalah variabel terbaik terhadap konsumsi bahan bakar, karena tidak berbeda nyata dengan RPM 800, namun hasil kinerjanya sama dengan kecepatan putar 1600 RPM.

\section{KESIMPULAN DAN SARAN}

\subsection{Kesimpulan}

Kesimpulan dari penelitian ini adalah

1. Kecepatan putar (RPM) berpengaruh terhadap kapasitas kerja, susut bobot, keberagaman cacahan, dan konsumsi bahan bakar

2. Kecepatan putar pencacahan terbaik berkisar antara 1200 RPM sampai 1600 RPM

3. Kecepatan putar 1200 RPM lebih menguntungkan dibanding kecepatan putar 1600 RPM, karena konsumsi bahan bakar yang lebih sedikit tetapi memiliki hasil kinerja yang sama dengan 1600 RPM

4. Persentase hasil cacahan yang dapat digunakan langsung sebagai ternak berkisar antara $37 \%-44 \%$.

\subsection{Saran}

Berdasarkan penelitian yang telah dilakukan, maka penulis memberikan saran sebagai berikut

1. Dilakukan modifikasi pada bagian input bahan dengan penambahan tempat untuk meletakkan pelepah kelapa sawit dengan sudut tertentu agar pengguna tidak perlu mendorong pelepah kelapa sawit dengan tujuan efisiensi tenaga kerja.

2. Hasil cacahan sebaiknya dicacah kembali dengan mesin pencacahan (chopper) untuk meningkatkan persentase cacahan yang sesuai untuk pakan ternak.

\section{DAFTAR PUSTAKA}

Anizar, Widyastuti, D.E., Torong, M.Z.B,. Hariyono, K. 2017. Perbaikan Disain Alat Pencacah Pelepah Sawit untuk Mengurangi Keluhan Sakit Peternak Sapi. Prosiding SNTI dan SATELIT A2 Th.2017.

Hermawan, H. 2015. Kajian Pengaruh Aplikasi Bionutrien S267 Terhadap Produktivitas Tanaman Kelapa Sawit TM-08. Universitas Pendidikan Indonesia

Sianipar, T. P. 2009. Efek Pelepah daun kelapa sawit dan limbah industrinya sebagai pakan terhadap pertumbuhan sapi Peranakan ongole pada fase pertumbuhan. Skripsi. Universitas Sumatera Utara.

Yusuf, M., Sulaeman, R., dan Sribudiani, E. 2014. Pemanfaatan Pelepah Kelapa Sawit ( elaeis guenensis jacq.) Sebagai Bahan Baku Pembuatan Briket Arang.Jurnal Online Mahasiswa Universitas Riau, Vol.1 No.1, 2-6, Th.2014 